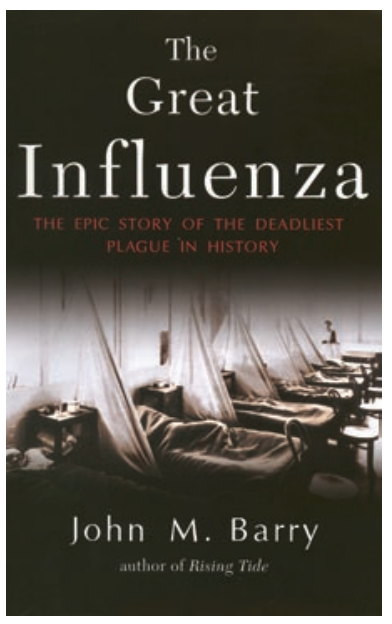

\title{
The great influenza
}

The epic story of the deadliest plague in history

John M. Barry

Viking Books, New York, New York, USA. 2004. 546 pp. \$29.95.

ISBN: 0-6708-9473-7 (hardcover).

Reviewed by Peter Palese

E-mail: peter.palese@mssm.edu

$\mathrm{T}$ he great influenza: the epic story of the deadliest plague in history is a great book. It is well conceived, well researched, and extremely well written. The appropriate audience goes beyond the interested physician, scientist, or medical student. The book will also appeal to history buffs, who will be fascinated by the dangerous mix of politics, war, and pestilence presented here. In the first third of the book, the word "influenza" rarely appears, because author John M. Barry is painting the landscape of science, medicine, and politics in the pre-World War I era. What comes to life in these pages is the sad state of US science and medicine at the time. For example, admission to US medical schools was dependent not on academic achievement, but rather on whether the applicant would pay the tuition. This changed with the Flexner Report, published in 1910 by Abraham Flexner, and with the establishment of such institutions as the Rockefeller Institute for Medical Research, ably led by Simon Flexner (brother of Abraham). As highlighted by Barry, the other major change leading to the modern era of American medicine was the founding of Johns Hopkins Medical School at the very end of the 19th century, with William Welch as the legendary force behind it. For anyone who has had the opportunity to interact with Johns Hopkins University, this introductory chapter in Barry's book is mandatory reading.

The writing is facile and gripping at the same time, and the author does an extraordinarily good job of creating a fluent narrative from historical research. Even when Barry describes the replication of the influenza virus in the cell, the writing is easily compre- hensible and convincing. He creates numerous wonderful images, such as likening the translation of a messenger RNA to reading Braille. When it comes to the actual influenza pandemic of 1918, Barry does a brilliant job. The facts of this extraordinary event are well presented and discussed. The reader is given the diverse data on the number of people who died during this pandemic; descriptions of those who did the analysis and the basis for arriving at the different numbers

\section{It is not a question of if, but when we will be faced with another epidemic of this magnitude.}

allow the reader to decide for him- or herself what the best estimates are. A conservative - and the most convincing - estimate is 50 million. In the context of the present world population of six billion, compared with two billion in 1918, this would translate into 150 million deaths today.

The political and military scene of 1917 as described by Barry is equally fascinating. Despite major scientific and public health advances, many of the influenza casualties resulted from uninformed and misguided decisions by military and political leaders. Hiram Johnson is quoted as saying, "The first casualty when war comes is truth.” This statement certainly remains true some eighty years later. When Barry recounts the suspicion that "German agents ... from submarines" are suspected of having brought influenza to the United
States, we can see that propaganda is not new either. Barry raises the frightening possibility that President Wilson was weakened by influenza in April 1919 and that this caused him to give in to the demands by the European allies, which resulted in the unfortunate outcome of the negotiations at Versailles.

The book is particularly powerful when it describes the actual disease and its effect on the population. The outbreak in Philadelphia must have been horrendous, with 4,597 influenza deaths in a single week. The effects of influenza in other parts of the world are described as equally harrowing. Barry quotes a report about an Alaskan village in which "... it was quite impossible to estimate the number of dead as the starving dogs had dug their way into many huts and devoured the dead..."

A few good things did come from this devastating pandemic. A restructuring of the country's public health system had its beginning as a direct result of the events of 1918 , and efforts were made to push for the establishment of the NIH, which became a reality about ten years later.

Overall, this book is engrossing reading, with plenty of relevance for our own time, which is threatened by natural (and/or deliberately released) emerging pathogens. It is a question not of if, but of when we will be faced with another epidemic of this magnitude. On the last page of the book, Victor Vaughan is quoted on the 1918 influenza pandemic: "Civilization could have disappeared within a few more weeks." 